\title{
Evaluation of Biogas through Chemically Treated Cottonseed Hull in Anaerobic Digestion with/without Cow Dung: An Experimental Study
}

Venkateshkumar R ( $\boldsymbol{\nabla}$ venkatthermal@gmail.com )

National Institute of Technology Tiruchirappalli https://orcid.org/0000-0003-1461-6722

Shanmugam S

National Institute of Technology Tiruchirappalli

Veerappan AR

National Institute of Technology Tiruchirappalli

\section{Research Article}

Keywords: Biogas, chemical pre-treatment, anaerobicdigestion, cow dung, cottonseed hull

Posted Date: December 29th, 2021

DOl: https://doi.org/10.21203/rs.3.rs-1022625/v1

License: (c) (i) This work is licensed under a Creative Commons Attribution 4.0 International License.

Read Full License 


\section{Abstract}

Cow dung is generally used as the feedstock material for the anaerobic digestion to produce biogas. A selection of alternate biomass material is needed to reduce the consumption or to eliminate the use of cow dung. Recently, cottonseed hull has been considered as the primary substrate to produce biogas. In this paper, the effect of biogas production on anaerobic co-digestion of cow dung with pre-treated cottonseed hull using different concentrations of sulfuric acid, hydrochloric acid, hydrogen peroxide, and acetic acid is investigated. Sodium hydroxide and calcium hydroxide are used at different concentrations for pre-treatment of cottonseed hull. The enhancement of biogas production from the batch reactors at mesophilic temperature $\left(35 \pm 2{ }^{\circ} \mathrm{C}\right)$ is observed for mono- and co-digestion of cow dung with treated cottonseed hull. Maximum biogas yield is achieved for the treated cottonseed hull at $6 \%$ sodium hydroxide during mono digestion and at $6 \%$ calcium hydroxide during co-digestion.

\section{Highlights}

- Anaerobic co-digestion of cow dung with chemically treated cotton seed hull can be enhanced biogas production.

- $3 \%$ acetic acid was best for biodegradability of cottonseed hull and enhancement of biogas yield in acid treated rectors.

- In alkaline treated reactors, $6 \%$ calcium hydroxide was best for biodegradability of cottonseed hull and enhancement of biogas yield.

- Optimized biogas production was observed on the anaerobic co-digestion of cow dung and $6 \%$ calcium hydroxide treated cotton seed hull at the ratio 75:25.

\section{Introduction}

In the present world, the increase in the human population is proportional to the increase in energy demand. Energy extracted from fossil fuel is mostly used which creates issues such as scarcity, expensive in price, and causes air pollution mainly affects the environment [1]. Previous studies also suggested using biogas as a clean energy source for power generation, cooking, and heating.

Furthermore, anaerobic digestion for biogas production is a potential option that may both augment and reduce the use of non-renewable energy sources like fossil fuels [2]. Cotton production is predicted to climb 4.7 percent globally by $2021 / 2022$, according to a forecast by the United States Department of Agriculture. However, there is a 6.5 percent reduction in comparison to $2019 / 2020$. China is predicted to be the largest producer, with 29.0 million bales of cotton, the highest level in the last six years, while India is estimated to produce roughly $475 \mathrm{~kg} /$ hectare, a $1 \%$ decrease from the previous year. India was first in cotton-producing countries in 2015, and second in 2019 and 2020, followed by the United States, Brazil, and Pakistan [3]. In India, surplus crop residue is composted, which takes up a lot of space, and then burned. Crop residues produce greenhouse gases when burned, contributing to increased air pollution [4]. Agricultural crop residues are used to produce biogas via anaerobic digestion to address this problem[5]. 
Agricultural crop residue such as cotton waste was generated around 11.4 Mt in India [6]. Appropriate technologies are employed for the production of clean energy to properly utilize waste and meet current energy requirements by reducing pollution. For the maximum degradation of organic waste, anaerobic digestion is the best technique opted for the generation of energy (Methane) in a more economical and environment-friendly manner $[7,8]$.

The alternative new renewable energy extraction can be done from biomass which could be a better solution. Biomass is the best alternative source that produces renewable energy and replaces fossil fuel products. Lignocellulose biomass comprises a large fraction of cellulose (40-50\%), a smaller fraction of hemicellulose (20-40\%), a very low fraction of lignin, and a small quantity of other alternatives. Cellulose is a glucose polymer with an average molecular weight of around 1,00,000, whereas hemicellulose is a heterogeneously branched polysaccharide with an average molecular weight of less than 30,000. Lignin has complex and cross-linked structures with high molecular weight. Lignocellulose biomass is difficult to degrade, naturally. For better degradation, a proper treatment method is followed [1]. The anaerobic biodegradability has been enhanced with the aid of treatment methodologies such as mechanical, thermal, chemical, ultrasonic, biological and microwave approaches through the anaerobic digestion process $[9,10]$. Biogas is produced through an anaerobic digestion process on various biomass materials such as wheat straw [11], pearl millet straw [12], corn stover [13, 14], rice straw[15], yard waste, and leaves [16], and also with other wastes such as food waste with cow dung [17], food waste with fresh septic tank sludge [18], etc.

Anaerobic co-digestion is a promising technique to enhance the digestion performance and biodegradability of lignocellulose biomass [19]. Among all the pre-treatment processes of biomass, the chemical pre-treatment process has been reported to offer maximum methane yield through the anaerobic digestion process with the effective breaking of chemical bonds among cellulose, hemicellulose, and lignin through microorganisms [20]. In the chemical treatment methods, the following chemicals are commonly used such as $\mathrm{H}_{2} \mathrm{SO}_{4}, \mathrm{HCl}, \mathrm{H}_{2} \mathrm{O}_{2}, \mathrm{CH}_{3} \mathrm{COOH}, \mathrm{NaOH}$ and $\mathrm{Ca}(\mathrm{OH})_{2}$ for the biodegradability of lignocellulosic biomass materials through an anaerobic digestion process [21]. $\mathrm{NaOH}$ and $\mathrm{Ca}(\mathrm{OH})_{2}$ are used as pre-treatment chemicals on giant reed materials for the enhancement of biogas production through anaerobic digestion [22]. Three plant species such as hay, straw, and bracken were pre-treated using $\mathrm{Ca}(\mathrm{OH})_{2}$, maleic acid, and ammonium carbonate, and subsequent anaerobic digestion was carried out under mesophilic temperature for 40 days in a batch digester [23]. The highest methane production was achieved by pre-treating corn stalk with $\mathrm{Ca}(\mathrm{OH})_{2}$ through an anaerobic co-digestion process with levulinic acid wastewater [24]. Pre-treated grass silage with $\mathrm{NaOH}$ increases biodegradability as well as biogas production through anaerobic digestion [25]. Sunflower stalks are pre-treated using various chemicals like $\mathrm{NaOH}, \mathrm{H}_{2} \mathrm{O}_{2}, \mathrm{Ca}(\mathrm{OH})_{2}, \mathrm{HCl}$, and $\mathrm{FeCl}_{3}$ to enhance methane production through anaerobic digestion [26]. Anaerobic co-digestion of cattle manure and corn stover was compared with that of ammonia solution and $\mathrm{NaOH}$ pre-treated samples which also results in higher methane yield under mesophilic conditions [27]. Pre-treatment of corn stalk using $\mathrm{H}_{2} \mathrm{SO}_{4}$ and $\mathrm{H}_{2} \mathrm{O}_{2}$ yields higher biogas production on the anaerobic co-digestion with swine manure [28]. Anaerobic co-digestion of cocoa pod 
husk with swine manure yields maximum biogas production where cocoa pod husk was pre-treated by using $\mathrm{H}_{2} \mathrm{SO}_{4}$ and $\mathrm{H}_{2} \mathrm{O}_{2}$ [29]. It was reported that methane production is directly proportional to the enzymatic degradation of the lignocellulose biomass, whereas methane potential is inversely related to the lignin content present in the lignocellulose biomass [16]. Remarkable biogas production was achieved on pre-treating $\mathrm{NaOH}$ with corn stover $[13,14,30]$ and Asparagus stover [31] in the anaerobic digestion process. Pre-treatment of rice straw with $\mathrm{H}_{2} \mathrm{O}_{2}$ used in biodegradation enhances biogas production [32]. Co-digestion of wheat straw with chemicals like $\mathrm{KOH}, \mathrm{Ca}(\mathrm{OH})_{2}$ results in higher biodegradability with the increase in biogas yield [33]. The main advantage of chemical pre-treatment on lignocellulosic biomass is to improve the effective biodegradability and upsurge the bioenergy production [21].

Naturally, agricultural biomass waste like cotton stalks was generally burnt and lead to air pollution. Cotton stalks can be effectively converted into useful energy through anaerobic digestion by various treated chemicals such as $\mathrm{KOH}, \mathrm{NaOH}, \mathrm{Ca}(\mathrm{OH})_{2}$, alkali Hydrogen per-oxide (AHP), $\mathrm{H}_{2} \mathrm{SO}_{4}, \mathrm{H}_{3} \mathrm{PO}_{4}$, and steam explosion method [34]. Wheat straw was pre-treated with $\mathrm{H}_{2} \mathrm{O}_{2}$ and also co-digested with cattle manure for the enhancement of biodegradability and also methane yield [35]. Cotton wastes such as cotton stalks, cottonseed hull (CSH), and cotton oil cake can be effectively converted for biogas production in the presence of basal medium through anaerobic digestion [36]. For sustainable environments, energy extraction has been done by performing effective pre-treatment studies to improve energy production [37].

Biochemical methane potential (BMP) test was conducted in an anaerobic co-digestion of cow dung (CD) with cottonseed hull (CSH) at different ratios (CD: CSH) i.e., 0:100, 50:50, 25:75, 75:25 and 100:0. Maximum biogas yield was obtained from the anaerobic co-digestion at the ratio of 75:25 among other proportions. Mono-digestion of CSH results in less biogas yield compared to the co-digestion of CD and $\mathrm{CSH}$ at the ratio of 75:25. From the previous studies, it is found that the optimum biogas yield is obtained from the anaerobic co-digestion of $\mathrm{CD}$ with $\mathrm{CSH}$ at the ratio of 75:25, and verified both experimentally [38] and using kinetic studies [39].

From the above literature review, it is found that the importance of chemical treatments on different biomass and the triggering of biogas generation through anaerobic digestion. Besides, the chemicals used for treatment break the bonding between the complex biomass structures in generating the anaerobes at a rapid rate. The $\mathrm{CSH}$ has the potential to generate biogas during mono- and co-digestion with $\mathrm{CD}$. Very few literatures have reported on the biogas generation from anaerobic mono- and codigestion of $\mathrm{CD}$ with chemically treated $\mathrm{CSH}$.

The performance of the digester with CD and CSH in the ratios of 75:25 and 0:100 with pre-treatment with various chemicals such as sulfuric acid, hydrochloric acid, hydrogen peroxide, acetic acid, sodium hydroxide, and calcium hydroxide at different concentrations for the enhancement of biogas yield has been investigated in this paper. The main objective of this paper is to find out the maximum biogas yield among all chemically pre-treated CSH and the best concentration in each acid and alkaline. The best- 
treated chemical for $\mathrm{CSH}$ for the complete replacement of $\mathrm{CD}$ in the existing gobar gas plant is also suggested.

\section{Materials And Methods}

\subsection{Feedstock material}

Feedstock material such as $\mathrm{CD}$ and $\mathrm{CSH}$ was collected from a local village in Karur city, Tamilnadu, India (Latitude $-10.69{ }^{\circ} \mathrm{N}$, Longitude $-78.42^{\circ} \mathrm{E}$ ). Before the usage of $\mathrm{CSH}$ material, air drying and shredding was done to make it into small particles with a spice pulverizer (Vikrem commercial heavy-duty pulverizer, India. Vik-9A model). Then, the material was sieved for 10 minutes through a particle sieve analyzer (make: Versatile equipment Private Limited, India) which ranges from $0.5 \mathrm{~mm}$ to $0.75 \mathrm{~mm}$. Fresh CD was collected from a small household located in the same village. The inoculum was taken from the batch anaerobic digester where $\mathrm{CD}$ was used as the main feedstock material at the same location. Prior to the BMP test, the collected feedstock material was kept at a temperature of $4{ }^{\circ} \mathrm{C}$. The effluent was maintained at a temperature of $37^{\circ} \mathrm{C}$ for seven days and dilute it with water[38]. The physical and chemical characteristics of the feedstock material are listed in Tables 1 and 2. CSH substrates consist of $32 \pm 2.1 \%$ cellulose, $18 \pm 0.9 \%$ hemicellulose and $20 \pm 1.7 \%$ lignin were founded using sequential extraction and weighing method [12].

Table 1

Physical characteristics of the feedstock materials used

\begin{tabular}{|c|c|c|c|c|c|}
\hline $\begin{array}{l}\text { Samples } \\
\text { used }\end{array}$ & $\begin{array}{l}\text { Moisture } \\
\text { present (\%) }\end{array}$ & $\begin{array}{l}\text { Total solid } \\
\text { (TS) (\%) }\end{array}$ & $\begin{array}{l}\text { Volatile solid } \\
\text { (VS) (\%) }\end{array}$ & $\begin{array}{l}\text { Fixed solid } \\
\text { (FS) (\%) }\end{array}$ & Reported \\
\hline Cow dung & $86 \pm 1$ & $14 \pm 1$ & $68 \pm 4$ & $32 \pm 4$ & \multirow[t]{3}{*}{ [38] } \\
\hline $\begin{array}{l}\text { Cotton seed } \\
\text { Hull }\end{array}$ & $11 \pm 0.1$ & $90 \pm 0.1$ & $90 \pm 0.1$ & $10 \pm 0.1$ & \\
\hline Inoculum & $92 \pm 0.1$ & $9 \pm 0.1$ & $62 \pm 0.2$ & $38 \pm 0.2$ & \\
\hline
\end{tabular}

Table 2

Chemical characteristics of the feedstock materials used

\begin{tabular}{|c|c|c|c|c|c|c|}
\hline $\begin{array}{l}\text { Feedstock } \\
\text { materials }\end{array}$ & Total C (\%) & $\begin{array}{l}\text { Total H } \\
\text { (\%) }\end{array}$ & $\begin{array}{l}\text { Total N } \\
\text { (\%) }\end{array}$ & $\begin{array}{l}\text { Total S } \\
\text { (\%) }\end{array}$ & $\begin{array}{l}\mathrm{C} / \mathrm{N} \\
\text { ratio }\end{array}$ & Reported \\
\hline Cow dung & $\begin{array}{l}39.64 \pm \\
1.25\end{array}$ & $\begin{array}{l}1.85 \pm \\
0.01\end{array}$ & $\begin{array}{l}1.21 \pm \\
0.02\end{array}$ & $\begin{array}{l}2.24 \pm \\
0.03\end{array}$ & 32.76 & [38] \\
\hline Cotton seed Hull & $38.31 \pm 0.3$ & $\begin{array}{l}2.24 \pm \\
0.25\end{array}$ & $\begin{array}{l}1.05 \pm \\
0.01\end{array}$ & $\begin{array}{l}1.47 \pm \\
0.01\end{array}$ & 36.38 & \\
\hline Inoculum & $30.36 \pm 1.5$ & $\begin{array}{l}0.88 \pm \\
0.02\end{array}$ & $\begin{array}{l}1.53 \pm \\
0.01\end{array}$ & $\begin{array}{l}1.37 \pm \\
0.02\end{array}$ & 19.91 & \\
\hline
\end{tabular}




\subsection{Pre-treatment}

A $500 \mathrm{ml}$-conical flask is filled with $300 \mathrm{ml}$ of distilled water and $100 \mathrm{~g}$ of CSH sample. Based on the weight/weight basis, acids and alkaline are added to the conical flask. From the previous study, the concentration of each acid and alkaline was chosen for the pre-treatment of $\mathrm{CSH}$ [21]. Acids are mixed with distilled water of proportions $1 \%, 2 \%$, and $3 \%$, whereas alkaline is mixed with distilled water at proportions $4 \%, 6 \%$, and $8 \%$, respectively. The conical flask was kept inside the incubator at a temperature of $25 \pm 2{ }^{\circ} \mathrm{C}$ for seven days. After the incubation period, all the samples were kept in the electric oven for two days at a temperature of $80^{\circ} \mathrm{C}$ [21]. Then, the dried samples were taken out without washing and again maintained at a temperature of $4{ }^{\circ} \mathrm{C}$ in the refrigerator until the start of the BMP test.

\subsection{Anaerobic digestion experiments}

Biogas production was determined through anaerobic digestion in a batch process with two sets of experiments. Each pre-treated CSH was used as the feedstock material, where untreated CSH was used as the control. In the first set of experiments, mono-digestion of acid and alkaline treated CSH was carried out at different concentrations. In the second set of experiments, co-digestion of CD and treated CSH at the ratio of 75:25 was carried out with the corresponding pre-treated $\mathrm{CSH}$ using early mentioned chemicals. All the experiments were conducted in a $0.5 \mathrm{~L}$ conical flask of which $0.3 \mathrm{~L}$ was taken as working volume. Each conical flask was filled with $0.3 \mathrm{~L}$ of inoculum, and feedstock material was added based on a final concentration of $1.5 \mathrm{gram}$ volatile solid (VS) per liter. The main reason for using inoculum from the anaerobic digestion process, which stimulates the methanogenic activity inside the batch reactors. All the conical flasks were stirred well and incubated under the mesophilic condition at a temperature of $35 \pm 2{ }^{\circ} \mathrm{C}$ for the digestion period of 45 days [40]. All the flasks were flushed with nitrogen, then closed by using a septa cap and kept in the incubator to create favorable conditions for generating anaerobes. Each flask was stirred manually for one minute before measuring the biogas yield. All the BMP tests with each sample were performed in duplicate.

\subsection{Analysis and calculations}

The volume of biogas produced from the digester was determined by using the water displacement method. The volume of biogas was finally calculated by subtracting it from the volume of biogas collected in the inoculum. Physical characteristics like total solid, volatile solid, fixed solid, and moisture content was found using standard methods (APHA 1995). Chemical characteristics like Carbon, Nitrogen was calculated using Vario EL III- Germany Elementar analyzer. C/N ratio was calculated as the ratio of total Carbon to total Nitrogen. $\mathrm{pH}$ values were determined using a $\mathrm{pH}$ meter ( $\mathrm{pH} 827$ modules, Metrohm India Ltd.). The composition of cellulose, hemicellulose, and lignin presented in CSH substrate was measured using sequential extraction and weighing method on a dry weight basis [12]. CSH samples were mixed in $75 \mathrm{ml}$ of water and boiled for one hour. Residing hot water was removed after an hour by adding fresh water and boil for one more hour. Then, the CSH samples were cleaned with cold water, and the sample was dried in an oven for 15 hours at a temperature of $60^{\circ} \mathrm{C}$ and weighed. The dried CSH sample was again mixed with $30 \mathrm{ml}$ of water, $2 \mathrm{ml}$ of acetic acid (i.e., $10 \%$ ), and $0.6 \mathrm{~g}$ of sodium chlorite, 
and heated at $75{ }^{\circ} \mathrm{C}$ for 1 hour to calculate the lignin content. Similar steps were followed one more time and heated for 2 hours. Distilled water, acetone, and ether were used to wash the CSH samples 5 times, 2 times, and 1 time, respectively. After that, the same CSH sample was dried at a temperature of $105^{\circ} \mathrm{C}$ for a one-and-half hours and weighed the sample. Hemicellulose content was calculated by appending $24 \%$ $\mathrm{KOH}$, i.e., $20 \mathrm{ml}$ and left in air at a temperature of $20^{\circ} \mathrm{C}$. Then the sample was soaked 5 times with water and one time into $5 \%$ acetic acid. Again, the same sample was bathed one more time with water, acetone, and ether. After bathing, the $\mathrm{CSH}$ sample was maintained at a temperature of $105^{\circ} \mathrm{C}$ for a one-and-half hours and weighed the same. The left-over weight of the $\mathrm{CSH}$ sample was considered as the weight of the cellulose content.

\section{Results And Discussion}

\subsection{Effect of pre-treatment on $\mathrm{pH}$}

Before anaerobic digestion, the initial $\mathrm{pH}$ values of all the reactors ranged from 7.21 to 7.44 which is mainly responsible for microbial growth and gives a positive impact on biogas production [42]. Since micro-organisms are more sensitive to $\mathrm{pH}$, methanogenic bacteria perform maximum reproduction over the $\mathrm{pH}$ range of 6.6 to 7.8 for biogas generation. After anaerobic digestion, the final $\mathrm{pH}$ values were from 7.08 to 7.48 for all the digesters at the end of 45 days. The $\mathrm{pH}$ values at the end of the anaerobic digestion process were stable when it lies within 7.5 [43]. $\mathrm{pH}$ values for the pre-treated acid and alkaline at various concentrations before and after the anaerobic digestion process are shown in Fig. 1 and Fig. 2 .

\subsection{Effect of chemical pre-treatment on mono-digestion 3.2.1 Effect of $\mathrm{H}_{2} \mathrm{SO}_{4}$ treated $\mathrm{CSH}$ on biogas generation with mono-digestion}

Maximum biogas yield of $120 \mathrm{ml} / \mathrm{g}$ VS was observed at $3 \%$ pre-treated $\mathrm{H}_{2} \mathrm{SO}_{4}$ with $\mathrm{CSH}$. There was no significant difference in biogas yield between $1 \%$ and $2 \% \mathrm{H}_{2} \mathrm{SO}_{4}$ treated $\mathrm{CSH}$ as the final yield was 106 $\mathrm{ml} / \mathrm{g}$ VS. Biogas yield was 3 to 4 -fold higher than untreated $\mathrm{CSH}$. The difference in biogas yield between treated CSH and untreated CSH was observed as $73 \mathrm{ml} / \mathrm{g} \mathrm{VS}, 73 \mathrm{ml} / \mathrm{g} \mathrm{VS}$, and $87 \mathrm{ml} / \mathrm{g} \mathrm{VS}$ at the concentration of $1 \%, 2 \%$, and $3 \% \mathrm{H}_{2} \mathrm{SO}_{4}$. Results produced are consistent in the previous study as the cumulative methane yield lies nearer range $176 \mathrm{ml} / \mathrm{g}$ VS for the $2 \% \mathrm{H}_{2} \mathrm{SO}_{4}$ treated corn straw [21]. The maximum biogas difference was observed as $34 \mathrm{ml} / \mathrm{g}$ VS between $3 \%$ pre-treated $\mathrm{H}_{2} \mathrm{SO}_{4}$ and codigestion of $\mathrm{CD}$ with untreated $\mathrm{CSH}$ at 75:25 (CD: $\mathrm{CSH}$ ). A higher concentration of pre-treated $\mathrm{CSH}$ with $\mathrm{H}_{2} \mathrm{SO}_{4}$ leads to maximum bioconversion which could improve biogas production.

\subsubsection{Effect of $\mathrm{HCl}$ treated CSH on biogas generation with mono-digestion}


Different concentration of $\mathrm{HCl}$ pre-treated CSH offers different biogas yields as compared to untreated $\mathrm{CSH}$. A higher biogas yield of $116 \mathrm{ml} / \mathrm{g}$ VS was observed at $1 \% \mathrm{HCl}$ pre-treated CSH. $73 \mathrm{ml} / \mathrm{g}$ VS and 87 $\mathrm{ml} / \mathrm{g}$ VS of biogas yield were observed for $2 \%$ and $3 \% \mathrm{HCl}$ treated $\mathrm{CSH}$. Results produced are persistent in the previous study as the cumulative methane yield lies nearer range $163 \mathrm{ml} / \mathrm{g} \mathrm{VS}$ for the $2 \% \mathrm{HCl}$ treated of corn straw [21]. The difference in biogas yield between treated CSH at the concentration of $1 \%, 2 \%$, and $3 \% \mathrm{HCl}$ and raw $\mathrm{CSH}$ was founded as 83,40 and $54 \mathrm{ml} / \mathrm{g} \mathrm{VS}$. $30 \mathrm{ml} / \mathrm{g}$ VS was observed as the difference in biogas yield at the $1 \% \mathrm{HCl}$ treated $\mathrm{CSH}$ and untreated $\mathrm{CSH}$ at the ratio of 75:25(CD: CSH). Cumulative biogas production from the treated $\mathrm{HCl}$ on $\mathrm{CSH}$ was 2 to 4 -fold greater than untreated $\mathrm{CSH}$. A lower concentration of $\mathrm{HCl}$ on pre-treated $\mathrm{CSH}$ also improves biodegradability.

\subsubsection{Effect of $\mathrm{H}_{2} \mathrm{O}_{2}$ treated $\mathrm{CSH}$ on biogas generation with mono-digestion}

$\mathrm{H}_{2} \mathrm{O}_{2}$ pre-treated CSH substrate offered cumulative biogas production of $91 \mathrm{ml} / \mathrm{g} \mathrm{VS}, 183 \mathrm{ml} / \mathrm{g} \mathrm{VS}$, and $171 \mathrm{ml} / \mathrm{g}$ VS respectively for $1 \%, 2 \%$, and $3 \%$ under hydraulic retention time (HRT) of 45 days. The cumulative methane yield reported in the previous study for the $3 \% \mathrm{H}_{2} \mathrm{O}_{2}$ pre-treated corn straw was observed as $217 \mathrm{ml} / \mathrm{g}$ VS [21]. It was observed that the difference of biogas yield between $\mathrm{H}_{2} \mathrm{O}_{2}$ treated at the concentration of $1 \%, 2 \%$, and $3 \%$ and raw $\mathrm{CSH}$ as 58,150 , and $138 \mathrm{ml} / \mathrm{g} \mathrm{VS}$. The maximum difference in biogas yield of $97 \mathrm{ml} / \mathrm{g}$ VS was observed between the $2 \% \mathrm{H}_{2} \mathrm{O}_{2}$ treated $\mathrm{CSH}$ and $\mathrm{CD}$ with untreated $\mathrm{CSH}$ at the ratio of 75:25(CD: CSH). More than 3 to 6 times higher biogas yield was observed over untreated $\mathrm{CSH}$. Increasing the loading of pre-treated $\mathrm{H}_{2} \mathrm{O}_{2}$ with $\mathrm{CSH}$ upsurge the bioconversion during anaerobic digestion.

\subsubsection{Effect of $\mathrm{CH}_{3} \mathrm{COOH}$ treated $\mathrm{CSH}$ on biogas generation with mono-digestion}

A total of $295 \mathrm{ml} / \mathrm{g} \mathrm{VS}$ of biogas yield was observed at $3 \% \mathrm{CH}_{3} \mathrm{COOH}$, whereas $202 \mathrm{ml} / \mathrm{g} \mathrm{VS}$ and 158 $\mathrm{ml} / \mathrm{g}$ VS were observed at $1 \%$ and $2 \%$, respectively. Previous results obtained cumulative methane yield as $145 \mathrm{ml} / \mathrm{g}$ VS for the $4 \% \mathrm{CH}_{3} \mathrm{COOH}$ treated on corn straw [21]. Biogas yield obtained at the difference between treated $1 \%, 2 \%$, and $3 \% \mathrm{CH}_{3} \mathrm{COOH}$ and raw $\mathrm{CSH}$ was 169,125 and $262 \mathrm{ml} / \mathrm{g}$ VS. Remarkable difference in biogas yield around $209 \mathrm{ml} / \mathrm{g}$ VS was observed between $3 \% \mathrm{CH}_{3} \mathrm{COOH}$ and untreated $\mathrm{CSH}$ at the ratio of 75:25 (CD: CSH). The maximum difference of $102 \mathrm{ml} / \mathrm{g}$ VS in yield was also observed between $3 \% \mathrm{CH}_{3} \mathrm{COOH}$ and $\mathrm{CD}$ alone. More than 5 to 9 -fold higher biogas yield was observed with untreated $\mathrm{CSH}$. The higher concentration of $\mathrm{CH}_{3} \mathrm{COOH}$ was directly related to the bioconversion of $\mathrm{CSH}$.

\subsubsection{Effect of $\mathrm{NaOH}$ treated CSH on biogas generation with mono-digestion}

Cumulative biogas yield of 212,430 , and $155 \mathrm{ml} / \mathrm{g}$ VS was observed respectively at $4 \%, 6 \%$, and $8 \%$ pretreated $\mathrm{NaOH}$ with $\mathrm{CSH}$. It was obvious from data that 5 to 13 -fold greater biogas yield was obtained raw $\mathrm{CSH}$ during the anaerobic digestion process. $8 \% \mathrm{NaOH}$ treated corn straw produced a cumulative 
methane yield of $164 \mathrm{ml} / \mathrm{g}$ VS [21]. The difference in biogas yield between the $\mathrm{NaOH}$ treated CSH at the concentration of $4 \%, 6 \%$, and $8 \%$ and untreated $\mathrm{CSH}$ was observed as 179,397 , and $122 \mathrm{ml} / \mathrm{g} \mathrm{VS}$. The maximum difference in biogas yield was observed as $344,237 \mathrm{ml} / \mathrm{g}$ VS with the $6 \%$ treated $\mathrm{NaOH}$ between untreated $\mathrm{CSH}$ at the ratio of 75:25 (CD: CSH) and CD. Medium concentration (6\%) of $\mathrm{NaOH}$ offered maximum biogas generation as compared to too low and too high concentrations.

\subsubsection{Effect of $\mathrm{Ca}(\mathrm{OH})_{2}$ treated $\mathrm{CSH}$ on biogas generation with mono-digestion}

Maximum biogas of $279 \mathrm{ml} / \mathrm{g}$ VS was produced for the $6 \% \mathrm{Ca}(\mathrm{OH})_{2}$ pre-treated $\mathrm{CSH}$, whereas $100 \mathrm{ml} / \mathrm{g}$ VS and $150 \mathrm{ml} / \mathrm{g}$ VS were observed for $4 \%$ and $8 \% \mathrm{Ca}(\mathrm{OH})_{2}$ pre-treated $\mathrm{CSH}$, respectively. This was 3 to 8 fold greater biogas yield compared to the mono-digestion of raw $\mathrm{CSH} .8 \% \mathrm{Ca}(\mathrm{OH})_{2}$ pre-treated corn straw produced a cumulative methane yield of $207 \mathrm{ml} / \mathrm{g} \mathrm{VS} \mathrm{[21].} 4 \%, 6 \%$, and $8 \% \mathrm{Ca}(\mathrm{OH})_{2}$ treated CSH produces a difference in biogas yield of 67,246 , and $117 \mathrm{ml} / \mathrm{g}$ VS with untreated $\mathrm{CSH}$. The maximum difference in biogas yield was observed as $193,86 \mathrm{ml} / \mathrm{g}$ VS with the $6 \%$ treated $\mathrm{Ca}(\mathrm{OH})_{2}$ between untreated $\mathrm{CSH}$ at the ratio of 75:25 (CD: $\mathrm{CSH}$ ) and $\mathrm{CD}$. Medium concentration $(6 \%)$ of $\mathrm{Ca}(\mathrm{OH})_{2}$ also offered maximum biogas yield compared to both too low and too high concentration cases.

\subsubsection{Acidic Vs alkaline treatment effect on mono-digestion}

With mono-digestion of pre-treated $\mathrm{CSH}$, the obtained biogas yield was found to follow the order, $6 \%$ $\mathrm{NaOH}>3 \% \mathrm{CH}_{3} \mathrm{COOH}>6 \% \mathrm{Ca}(\mathrm{OH})_{2}>2 \% \mathrm{H}_{2} \mathrm{O}_{2}>3 \% \mathrm{H}_{2} \mathrm{SO}_{4}>1 \% \mathrm{HCl}$ where the obtained cumulative biogas yields respectively were $430 \pm 11 \mathrm{ml} / \mathrm{g}$ VS, $295 \pm 9 \mathrm{ml} / \mathrm{g} \mathrm{VS}, 279 \pm 14 \mathrm{ml} / \mathrm{g} \mathrm{VS}, 183 \pm 11 \mathrm{ml} / \mathrm{g} \mathrm{VS}$, $120 \pm 9 \mathrm{ml} / \mathrm{g} \mathrm{VS}$, and $116 \pm 9 \mathrm{ml} / \mathrm{g}$ VS. A previous study also reports that the maximum concentration of alkaline added to lignocellulose material does not produce any effect on chemical links between lignin and hemicellulose, which only reduces the lignin solubilization [44]. The difference in maximum biogas yield between acid and alkaline treated CSH during mono-digestion is around $135 \mathrm{ml} / \mathrm{g}$ VS. Pre-treatment on lignocellulose biomass was reported to improve biogas production by accelerating the growth of the micro-organisms at a rapid reaction rate through an anaerobic digestion process [45]. Effective alkaline treatment had a high potential to increase the biogas yield since it degrades the biomass completely by reducing the lignin content during anaerobic digestion $[46,47]$.

\subsection{Effect of chemical pre-treatment on co-digestion 3.3.1 Effect of $\mathrm{H}_{2} \mathrm{SO}_{4}$ treated $\mathrm{CSH}$ on biogas generation with co-digestion of $\mathrm{CD}$}

$75 \%$ of Cow dung was co-digested with $25 \%$ pre-treated $\mathrm{H}_{2} \mathrm{SO}_{4}$ through anaerobic digestion process yields cumulative biogas of 197,106 , and $126 \mathrm{ml} / \mathrm{g}$ VS for the concentration of $1 \%, 2 \%$, and $3 \% \mathrm{H}_{2} \mathrm{SO}_{4}$, respectively. This was 3 to 6 -fold greater biogas yield over raw $\mathrm{CSH}$, whereas 1 to 2 -fold greater yield was obtained over co-digestion of CD with raw CSH at the same ratio. 164,73, and $93 \mathrm{ml} / \mathrm{g}$ VS was observed 
as the difference in biogas yield between $1 \%, 2 \%, 3 \% \mathrm{H}_{2} \mathrm{SO}_{4}$ treated and untreated $\mathrm{CSH}$. The maximum biogas difference of $111,4 \mathrm{ml} / \mathrm{g}$ VS was observed with the $1 \% \mathrm{H}_{2} \mathrm{SO}_{4}$ treated $\mathrm{CSH}$ between untreated $\mathrm{CSH}$ at the ratio of 75:25 (CD: CSH) and CD. A lower concentration of pre-treated $\mathrm{H}_{2} \mathrm{SO}_{4}$ itself enhances the maximal biodegradability of $\mathrm{CSH}$.

\subsubsection{Effect of $\mathrm{HCl}$ treated $\mathrm{CSH}$ on biogas generation with co-digestion of CD}

200,170 , and $173 \mathrm{ml} / \mathrm{g}$ VS of biogas were generated during the co-digestion (75:25) of CD with $\mathrm{HCl}$ pretreated for the concentration of $1 \%, 2 \%$, and $3 \%$, respectively. This was a 5 to 6 -fold increment achieved over mono-digestion of untreated $\mathrm{CSH}$ and also 2-fold greater than co-digestion of $\mathrm{CD}$ with untreated CSH at the same ratio. 167,137 , and $140 \mathrm{ml} / \mathrm{g}$ VS was obtained as the biogas yield difference between $1 \%$, $2 \%, 3 \% \mathrm{HCl}$ treated and raw $\mathrm{CSH} .1 \% \mathrm{HCl}$ treated $\mathrm{CSH}$ resulted in maximum biogas difference as 114,7 $\mathrm{ml} / \mathrm{g}$ VS between untreated CSH at the ratio of 75:25 (CD: CSH) and CD. Results revealed that a lower concentration of $\mathrm{HCl}$ produced maximum biogas generation.

\subsubsection{Effect of $\mathrm{H}_{2} \mathrm{O}_{2}$ treated $\mathrm{CSH}$ on biogas generation with co-digestion of CD}

The co-digestion (75:25) of $\mathrm{CD}$ with pre-treated $\mathrm{H}_{2} \mathrm{O}_{2}$ on $\mathrm{CSH}$ yielded cumulative biogas of 139,195 and $145 \mathrm{ml} / \mathrm{g}$ VS for $1 \%, 2 \%$, and $3 \%$ concentrations, respectively, which was 4 to 6 -fold higher than monodigestion of untreated CSH. Similarly, this yield was 2-fold greater than the one obtained with co-digestion of $\mathrm{CD}$ with untreated $\mathrm{CSH}$ at the same ratio. The biogas yield difference was observed as $106,162,112$ $\mathrm{ml} / \mathrm{g}$ VS between the $1 \%, 2 \%, 3 \% \mathrm{H}_{2} \mathrm{O}_{2}$ treated and untreated $\mathrm{CSH}$. A remarkable biogas yield difference was noticed as 109, $2 \mathrm{ml} / \mathrm{g}$ VS between untreated $\mathrm{CSH}$ at the ratio of 75:25 (CD: $\mathrm{CSH}$ ) and CD at the $2 \%$ $\mathrm{H}_{2} \mathrm{O}_{2}$ treated $\mathrm{CSH}$. The medium concentration of treated $\mathrm{H}_{2} \mathrm{O}_{2}$ on $\mathrm{CSH}$ leads to maximum biogas generation.

\subsubsection{Effect of $\mathrm{CH}_{3} \mathrm{COOH}$ treated $\mathrm{CSH}$ on biogas generation with co-digestion of $\mathrm{CD}$}

277,171 , and $345 \mathrm{ml} / \mathrm{g}$ VS of biogas were produced during the co-digestion (75:25) of $\mathrm{CD}$ with $\mathrm{CH}_{3} \mathrm{COOH}$ pre-treated $\mathrm{CSH}$ for the concentration of $1 \%, 2 \%$, and $3 \%$ which was 5 to 10 -fold greater than the yield obtained with mono-digestion of untreated $\mathrm{CSH}$, and 2 to 4 -fold greater than the yield obtained with codigestion of $\mathrm{CD}$ with untreated $\mathrm{CSH}$ for the same ratio. The biogas yield difference between $1 \%, 2 \%, 3 \%$ $\mathrm{CH}_{3} \mathrm{COOH}$ treated and untreated $\mathrm{CSH}$ was observed as 244,138 , and $312 \mathrm{ml} / \mathrm{g}$ VS. At $3 \% \mathrm{CH}_{3} \mathrm{COOH}$ treated $\mathrm{CSH}$, the maximum biogas yield difference was observed as $259,152 \mathrm{ml} / \mathrm{g}$ VS between the untreated $\mathrm{CSH}$ at the ratio of 75:25 (CD: $\mathrm{CSH}$ ) and $\mathrm{CD}$. A higher concentration of $\mathrm{CH}_{3} \mathrm{COOH}$ treated $\mathrm{CSH}$ leads to maximum biogas generation. 


\subsubsection{Effect of $\mathrm{NaOH}$ treated $\mathrm{CSH}$ on biogas generation with co-digestion of CD}

During the anaerobic co-digestion (75:25) of CD with pre-treated $\mathrm{NaOH}$ on $\mathrm{CSH}$ yielded cumulative biogas of 166,395 , and $104 \mathrm{ml} / \mathrm{g}$ VS for the concentrations of $4 \%, 6 \%$, and $8 \%$, respectively which was 3 to $12-$ fold higher than mono-digestion of untreated $\mathrm{CSH}$, and 1 to 5 -fold greater than the yield achieved during the co-digestion of CD with untreated $\mathrm{CSH}$ at the same ratio. The biogas yield difference was observed as $133,362,71 \mathrm{ml} / \mathrm{g}$ VS between the $4 \%, 6 \%, 8 \% \mathrm{NaOH}$ treated and untreated $\mathrm{CSH}$. A remarkable biogas yield difference was noticed as 309, $202 \mathrm{ml} / \mathrm{g}$ VS between untreated CSH at the ratio of 75:25 (CD: CSH) and $\mathrm{CD}$ at the $6 \% \mathrm{NaOH}$ treated $\mathrm{CSH}$. The medium concentration of treated $\mathrm{CSH}$ with $\mathrm{NaOH}$ yielded maximum biogas generation.

\subsubsection{Effect of $\mathrm{Ca}(\mathrm{OH})_{2}$ treated $\mathrm{CSH}$ on biogas generation with co-digestion of $\mathrm{CD}$}

151,489 , and $431 \mathrm{ml} / \mathrm{g}$ VS of biogas were generated during anaerobic co-digestion (75:25) of CD with treated $\mathrm{Ca}(\mathrm{OH})_{2}$ for the concentrations of $4 \%, 6 \%$, and $8 \%$, respectively. It was observed that 5 to 15 -fold greater yield was achieved over the mono-digestion of untreated $\mathrm{CSH}$, and a 2 to 6 -fold higher yield was achieved over the co-digestion of $\mathrm{CD}$ with untreated $\mathrm{CSH}$ at the same ratio. The biogas yield difference between $4 \%, 6 \%, 8 \% \mathrm{Ca}(\mathrm{OH})_{2}$ treated and untreated $\mathrm{CSH}$ was observed as 118,456 , and $398 \mathrm{ml} / \mathrm{g} \mathrm{VS}$. At $3 \% \mathrm{Ca}(\mathrm{OH})_{2}$ treated $\mathrm{CSH}$, the maximum biogas yield difference was observed as $403,296 \mathrm{ml} / \mathrm{g}$ VS between the untreated $\mathrm{CSH}$ at the ratio of 75:25 (CD: CSH) and CD. The medium concentration of treated $\mathrm{CSH}$ with $\mathrm{Ca}(\mathrm{OH})_{2}$ yielded maximum biogas generation.

\subsubsection{Acidic Vs alkaline treatment effect on co-digestion}

The co-digestion of CD with pre-treated CSH at the ratio of $75: 25$, resulted in the cumulative biogas production of $489 \pm 12 \mathrm{ml} / \mathrm{g} \mathrm{VS}, 395 \pm 16 \mathrm{ml} / \mathrm{g} \mathrm{VS}, 345 \pm 9 \mathrm{ml} / \mathrm{g} \mathrm{VS}, 200 \pm 9 \mathrm{ml} / \mathrm{g} \mathrm{VS}, 197 \pm 8 \mathrm{ml} / \mathrm{g} \mathrm{VS}$, $195 \pm 9 \mathrm{ml} / \mathrm{g}$ VS (ranked in the order of $6 \% \mathrm{Ca}(\mathrm{OH})_{2}>6 \% \mathrm{NaOH}>3 \% \mathrm{CH}_{3} \mathrm{COOH}>1 \% \mathrm{HCl}>1 \% \mathrm{H}_{2} \mathrm{SO}_{4}>$ $2 \% \mathrm{H}_{2} \mathrm{O}_{2}$ ). The maximum difference in biogas yield of $144 \mathrm{ml} / \mathrm{g} \mathrm{VS}$ is observed during co-digestion of $\mathrm{CD}$ with acid and alkaline treated CSH (75:25). The cumulative biogas production on both untreated CD and $\mathrm{CSH}$ at different ratios were observed to be $193 \pm 6 \mathrm{ml} / \mathrm{g} \mathrm{VS} \mathrm{(100:0),} 33 \pm 2 \mathrm{ml} / \mathrm{g} \mathrm{VS} \mathrm{(0:100),} \mathrm{and} 86 \pm 7$ $\mathrm{ml} / \mathrm{g}$ VS (75:25) after 45 days[38].

The cumulative biogas yield from the treated $\mathrm{CSH}$ with the chemical concentration of $1 \% \mathrm{CH}_{3} \mathrm{COOH}, 3 \%$ $\mathrm{CH}_{3} \mathrm{COOH}, 4 \% \mathrm{NaOH}, 6 \% \mathrm{NaOH}, 6 \% \mathrm{Ca}(\mathrm{OH})_{2}$ produces the maximum results as compared with the $\mathrm{CD}$ alone. All other untreated CD with chemically pre-treated CSH produces extraordinary cumulative biogas production when compared to the untreated CD with $\mathrm{CSH}$ for the ratio of 75:25. Untreated CSH offered only very low cumulative biogas production as compared with both chemically treated CSH and untreated CD. In the $100 \%$ pre-treated CSH, the maximum biogas generation was seen through the mono-digestion process, especially in $6 \%$ pre-treated $\mathrm{NaOH}$, whereas in the co-digestion of $\mathrm{CD}$ with pre-treated $\mathrm{CSH}$, it was 
observed for the $6 \%$ of $\mathrm{Ca}(\mathrm{OH})_{2}$. Table 3 describes the cumulative biogas production of untreated $\mathrm{CD}$ and $\mathrm{CSH}$ at the ratio of 100:0, 0:100, 75:25 along with the treated $\mathrm{CSH}, 0: 100$, and 75:25. 
Table 3

Cumulative biogas production for all the reactors

\begin{tabular}{|c|c|c|}
\hline Blend ratio & $\begin{array}{l}\text { Chemicals } \\
\text { treated }\end{array}$ & $\begin{array}{l}\text { Cumulative Biogas yield }(\mathrm{ml} / \mathrm{g} \\
\text { VS) }\end{array}$ \\
\hline CD (100:0) & $0 \%$ & $193 \pm 16$ \\
\hline Untreated CSH (0:100) & $0 \%$ & $33 \pm 2$ \\
\hline $\begin{array}{l}\text { Untreated CD with CSH } \\
(75: 25)\end{array}$ & $0 \%$ & $86 \pm 7$ \\
\hline Treated CSH (0:100) & $1 \% \mathrm{H}_{2} \mathrm{SO}_{4}$ & $106 \pm 11$ \\
\hline Treated CSH $(0: 100)$ & $2 \% \mathrm{H}_{2} \mathrm{SO}_{4}$ & $106 \pm 9$ \\
\hline Treated CSH (0:100) & $3 \% \mathrm{H}_{2} \mathrm{SO}_{4}$ & $120 \pm 9$ \\
\hline Treated CSH $(0: 100)$ & $1 \% \mathrm{HCl}$ & $116 \pm 9$ \\
\hline Treated CSH $(0: 100)$ & $2 \% \mathrm{HCl}$ & $73 \pm 13$ \\
\hline Treated CSH $(0: 100)$ & $3 \% \mathrm{HCl}$ & $87 \pm 11$ \\
\hline Treated CSH (0:100) & $1 \% \mathrm{H}_{2} \mathrm{O}_{2}$ & $91 \pm 12$ \\
\hline Treated CSH $(0: 100)$ & $2 \% \mathrm{H}_{2} \mathrm{O}_{2}$ & $183 \pm 11$ \\
\hline Treated CSH (0:100) & $3 \% \mathrm{H}_{2} \mathrm{O}_{2}$ & $171 \pm 10$ \\
\hline Treated CSH (0:100) & $1 \% \mathrm{CH}_{3} \mathrm{COOH}$ & $202 \pm 9$ \\
\hline Treated CSH (0:100) & $2 \% \mathrm{CH}_{3} \mathrm{COOH}$ & $158 \pm 9$ \\
\hline Treated CSH $(0: 100)$ & $3 \% \mathrm{CH}_{3} \mathrm{COOH}$ & $295 \pm 9$ \\
\hline Treated CSH (0:100) & $4 \% \mathrm{NaOH}$ & $212 \pm 11$ \\
\hline Treated CSH (0:100) & $6 \% \mathrm{NaOH}$ & $430 \pm 11$ \\
\hline Treated CSH $(0: 100)$ & $8 \% \mathrm{NaOH}$ & $155 \pm 13$ \\
\hline Treated CSH (0:100) & $4 \% \mathrm{Ca}(\mathrm{OH})_{2}$ & $100 \pm 9$ \\
\hline Treated CSH (0:100) & $6 \% \mathrm{Ca}(\mathrm{OH})_{2}$ & $279 \pm 14$ \\
\hline Treated CSH $(0: 100)$ & $8 \% \mathrm{Ca}(\mathrm{OH})_{2}$ & $150 \pm 8$ \\
\hline CD with treated $\mathrm{CSH}(75: 25)$ & $1 \% \mathrm{H}_{2} \mathrm{SO}_{4}$ & $197 \pm 8$ \\
\hline CD with treated CSH $(75: 25)$ & $2 \% \mathrm{H}_{2} \mathrm{SO}_{4}$ & $106 \pm 9$ \\
\hline
\end{tabular}




\begin{tabular}{|c|c|c|}
\hline Blend ratio & $\begin{array}{l}\text { Chemicals } \\
\text { treated }\end{array}$ & $\begin{array}{l}\text { Cumulative Biogas yield }(\mathrm{ml} / \mathrm{g} \\
\text { VS) }\end{array}$ \\
\hline CD with treated $\mathrm{CSH}(75: 25)$ & $3 \% \mathrm{H}_{2} \mathrm{SO}_{4}$ & $126 \pm 9$ \\
\hline CD with treated CSH $(75: 25)$ & $1 \% \mathrm{HCl}$ & $200 \pm 9$ \\
\hline CD with treated CSH $(75: 25)$ & $2 \% \mathrm{HCl}$ & $170 \pm 8$ \\
\hline CD with treated CSH $(75: 25)$ & $3 \% \mathrm{HCl}$ & $173 \pm 9$ \\
\hline $\mathrm{CD}$ with treated $\mathrm{CSH}(75: 25)$ & $1 \% \mathrm{H}_{2} \mathrm{O}_{2}$ & $139 \pm 8$ \\
\hline CD with treated CSH $(75: 25)$ & $2 \% \mathrm{H}_{2} \mathrm{O}_{2}$ & $195 \pm 9$ \\
\hline $\mathrm{CD}$ with treated $\mathrm{CSH}(75: 25)$ & $3 \% \mathrm{H}_{2} \mathrm{O}_{2}$ & $145 \pm 7$ \\
\hline CD with treated CSH $(75: 25)$ & $1 \% \mathrm{CH}_{3} \mathrm{COOH}$ & $277 \pm 14$ \\
\hline $\mathrm{CD}$ with treated $\mathrm{CSH}(75: 25)$ & $2 \% \mathrm{CH}_{3} \mathrm{COOH}$ & $171 \pm 9$ \\
\hline CD with treated CSH $(75: 25)$ & $3 \% \mathrm{CH}_{3} \mathrm{COOH}$ & $345 \pm 9$ \\
\hline CD with treated CSH $(75: 25)$ & $4 \% \mathrm{NaOH}$ & $166 \pm 8$ \\
\hline CD with treated CSH $(75: 25)$ & $6 \% \mathrm{NaOH}$ & $395 \pm 16$ \\
\hline CD with treated CSH $(75: 25)$ & $8 \% \mathrm{NaOH}$ & $104 \pm 9$ \\
\hline CD with treated $\mathrm{CSH}(75: 25)$ & $4 \% \mathrm{Ca}(\mathrm{OH})_{2}$ & $151 \pm 11$ \\
\hline CD with treated CSH $(75: 25)$ & $6 \% \mathrm{Ca}(\mathrm{OH})_{2}$ & $489 \pm 12$ \\
\hline CD with treated $\mathrm{CSH}(75: 25)$ & $8 \% \mathrm{Ca}(\mathrm{OH})_{2}$ & $431 \pm 12$ \\
\hline
\end{tabular}

Remarkably, biogas production was enhanced through co-digestion of CD with pre-treated CSH when compared with mono-digestion of $\mathrm{CD}$ and $\mathrm{CSH}$. Previous studies were also reported that maximum biogas production achieved through the co-digestion process which indicates the greater solubility and the biodegradability of hemicellulose, cellulose, and lignin. This in turn shows the importance of anaerobic bacteria [35].

\subsection{Comparison of acid and alkaline pre-treated CSH on biogas production}

The biodegradability of lignocellulosic material mainly depends on the degradation of cellulose, hemicellulose, and lignin. Lignin plays a major role in biodegradation in anaerobic conditions [48]. For higher biodegradability, lignin content present in the lignocellulosic material must be lower. If lignin content is more in the lignocellulosic material, the solubilization rate will be low, and special chemical treatment will create a positive effect on biodegradability $[16,23,42]$. Alkali treatments are best in 
maximum solubilization of hemicellulose and lignin since they broke the chemical bonded linkages on ester bonds between them presented on the cell wall $[10,49]$. Maximum methane yield was observed when there was greater enzymatic degradation, and contents of cellulose and hemicellulose with less lignin in the biomass $[16,45,50]$. Saturated lignocellulose presented in biomass samples sinks the biogas production, whereas alkaline pre-treatment upsurge the biogas production through the increase of microbial fermentative organism available in the soluble organic substance $[35,45,50,51]$.

In the acid pre-treatment of $\mathrm{CSH}$, the maximum biogas production was observed in the $3 \% \mathrm{CH}_{3} \mathrm{COOH}$ whereas, in the alkaline pre-treatment of $\mathrm{CSH}$, maximum biogas production was observed in the $6 \% \mathrm{NaOH}$ from the mono-digestion of CSH. For the co-digestion of $75 \% \mathrm{CD}$ with $25 \%$ of pre-treated $\mathrm{CSH}$, the maximum biogas was produced in the $3 \% \mathrm{CH}_{3} \mathrm{COOH}$ in the acid pre-treatment and $6 \% \mathrm{Ca}(\mathrm{OH})_{2}$ in the alkaline pre-treatment. During mono digestion of treated $\mathrm{CSH}, 13$-fold improvement was observed at $6 \%$ $\mathrm{NaOH}$ over untreated $\mathrm{CSH}$, whereas in co-digestion of $\mathrm{CD}$ with treated $\mathrm{CSH}$, it is achieved 15 -fold improvement over untreated $\mathrm{CSH}$ at $6 \% \mathrm{Ca}(\mathrm{OH})_{2}$. This result was consistent with a previous study where biogas production was up to $162.2 \%$ [44] and also $\mathrm{CD}$ co-digested with $6 \%$ of $\mathrm{Ca}(\mathrm{OH})_{2}$ pre-treated $\mathrm{CSH}$ at the ratio $75: 25$ increased by $153.4 \%$. This implies that co-digestion improves the biodegradability of $\mathrm{CSH}$ when compared with mono-digestion of pre-treated CSH. The major advantage of alkaline pre-treatment on lignocellulose biomass was to broke the ester bonds and disintegrate cellulose, hemicellulose, and lignin content to reduce the digestion time and also to improve the biogas production. Previous researchers also reported that $6 \%$ of alkaline pre-treatment on lignocellulose biomass showed the best results of biogas production among other concentrations [31,52,53]. Too low or too high concentration of alkaline pre-treatment may affect the anaerobic degradation of biomass substrate which will result in lower biogas yield. Acid pre-treatment on lignocellulose biomass substrate resulted in maximum biogas production at a lower concentration. Since it degrades the structure of the substrate and creates the composition favorable to generate micro anaerobes. At higher concentrations, lower biogas yield was obtained as it loses the substrates of dry matter rapidly which inhibits the growth of micro-organisms [52]. Results shown in the current study were consistent with previous studies and it can be concluded that alkaline pre-treatment will produce maximum biogas yield as compared to acid pre-treatment on various biomass substrates [53-55]. For the HRT of 45 days, with different chemically pre-treated CSH, the corresponding biogas production is shown in Fig. 3 and Fig. 4.

\section{Conclusions}

The variation of biogas production on anaerobic digestion of chemically treated mono-digestion of cottonseed hull and co-digestion of cow dung with treated cottonseed hull was studied under batch digester conducted for 45 days. Remarkable biogas production was achieved in the co-digestion of cow dung with treated cottonseed hull at the ratio of 75:25 when compared with the treated mono-digestion of cottonseed hull. Among all digesters, it was observed that $153.4 \%$ of biogas production in the codigestion of $75 \%$ cottonseed hull treated with $6 \%$ calcium hydroxide as compared to untreated $25 \%$ cow dung. It is suggested that pre-treated $75 \%$ cottonseed hull at $6 \%$ calcium hydroxide will replace $75 \%$ of 
cow dung consumption in the existing biogas plant with increased biogas production. Among various acid pre-treatments, $3 \%$ acetic acid was best for biodegradability of cottonseed hull and enhancement of biogas yield and in alkaline pre-treatments, $6 \%$ calcium hydroxide was best. Chemical pre-treatment on cottonseed hull enhances biogas production with reduced duration of digestion time compared with untreated cottonseed hull.

\section{Declarations}

competing InterestsThe authors declare that they have no known competing financial interests or personal relationships that could have appeared to influence the work reported in this paper.

\section{Acknowledgment}

We would like to record our sincere thanks to Dr.R. Gandhimathi, Associate Professor, and Professor G. Swaminathan, Head, Department of Civil Engineering, National Institute of Technology, Tiruchirappalli for providing opportunities to utilize the facilities in Environmental Laboratory.

\section{References}

1. McKendry P (2002) Energy production from biomass (part 1): overview of biomass. Bioresource Technology 83:37-46. https://doi.org/10.1016/S0960-8524(01)00118-3

2. Obileke K, Nwokolo N, Makaka G, et al (2021) Anaerobic digestion: Technology for biogas production as a source of renewable energy-A review. Energy \& Environment 32:191-225. https://doi.org/10.1177/0958305X20923117

3. Johnson J, MacDonald S, Meyer L, Soley G(2021) THE WORLD AND UNITED STATES COTTON OUTLOOK. accessed on February 18-19, $2021 \cdot \mathrm{https} / / /$ www.usda.gov/oce/ag-outlook-forum

4. Andreae MO, Merlet $P$ (2001) Emission of trace gases and aerosols from biomass burning. Global Biogeochem Cycles 15:955-966. https://doi.org/10.1029/2000GB001382

5. Nguyen VH, Topno S, Balingbing C, et al (2016) Generating a positive energy balance from using rice straw for anaerobic digestion. Energy Reports 2:117-122. https://doi.org/10.1016/j.egyr.2016.05.005

6. Devi S, Gupta C, Jat SL, Parmar MS (2017) Crop residue recycling for economic and environmental sustainability: The case of India. Open Agriculture 2:. https://doi.org/10.1515/opag-2017-0053

7. Paritosh K, Yadav M, Chawade A, et al (2020) Additives as a Support Structure for Specific Biochemical Activity Boosts in Anaerobic Digestion: A Review. Front Energy Res 8:88. https://doi.org/10.3389/fenrg.2020.00088

8. Chandra R, Takeuchi H, Hasegawa $T$ (2012) Methane production from lignocellulosic agricultural crop wastes: A review in context to second generation of biofuel production. Renewable and Sustainable Energy Reviews 16:1462-1476. https://doi.org/10.1016/j.rser.2011.11.035 
9. Paritosh K, Yadav M, Mathur S, et al (2018) Organic Fraction of Municipal Solid Waste: Overview of Treatment Methodologies to Enhance Anaerobic Biodegradability. Front Energy Res 6:75. https://doi.org/10.3389/fenrg.2018.00075

10. Sun S, Sun S, Cao X, Sun R (2016) The role of pretreatment in improving the enzymatic hydrolysis of lignocellulosic materials. Bioresource Technology 199:49-58. https://doi.org/10.1016/j.biortech.2015.08.061

11. Paritosh K, Vivekanand V (2019) Biochar enabled syntrophic action: Solid state anaerobic digestion of agricultural stubble for enhanced methane production. Bioresource Technology 289:121712. https://doi.org/10.1016/j.biortech.2019.121712

12. Paritosh K, Balan V, Vijay VK, Vivekanand V (2020) Simultaneous alkaline treatment of pearl millet straw for enhanced solid state anaerobic digestion: Experimental investigation and energy analysis. Journal of Cleaner Production 252:119798. https://doi.org/10.1016/j.jclepro.2019.119798

13. Zheng M, Li X, Li L, et al (2009) Enhancing anaerobic biogasification of corn stover through wet state $\mathrm{NaOH}$ pretreatment. Bioresource Technology 100:5140-5145.

https://doi.org/10.1016/j.biortech.2009.05.045

14. Zhu J, Wan C, Li Y (2010) Enhanced solid-state anaerobic digestion of corn stover by alkaline pretreatment. Bioresource Technology 101:7523-7528.

https://doi.org/10.1016/j.biortech.2010.04.060

15. Chen G-Y, Cao H-N, Fan X-Q, et al (2021) Investigating the effect of compaction on the anaerobic digestion process of rice straw. Bioenerg Res. https://doi.org/10.1007/s12155-021-10347-4

16. Liew LN, Shi J, Li Y (2012) Methane production from solid-state anaerobic digestion of lignocellulosic biomass. Biomass and Bioenergy 46:125-132. https://doi.org/10.1016/j.biombioe.2012.09.014

17. Kesharwani N, Bajpai S (2021) Pilot scale anaerobic co-digestion at tropical ambient temperature of India: Digester performance and techno-economic assessment. Bioresource Technology Reports 15:100715. https://doi.org/10.1016/j.biteb.2021.100715

18. Kesharwani N, Bajpai S (2020) Batch anaerobic co-digestion of food waste and sludge: a multi criteria decision modelling (MCDM) approach. SN Appl Sci 2:1467. https://doi.org/10.1007/s42452020-03265-1

19. Sawatdeenarunat C, Surendra KC, Takara D, et al (2015) Anaerobic digestion of lignocellulosic biomass: Challenges and opportunities. Bioresource Technology 178:178-186. https://doi.org/10.1016/j.biortech.2014.09.103

20. Kumar S, Paritosh K, Pareek N, et al (2018) De-construction of major Indian cereal crop residues through chemical pretreatment for improved biogas production: An overview. Renewable and Sustainable Energy Reviews 90:160-170. https://doi.org/10.1016/j.rser.2018.03.049

21. Song Z, GaiheYang, Liu X, et al (2014) Comparison of Seven Chemical Pretreatments of Corn Straw for Improving Methane Yield by Anaerobic Digestion. PLoS ONE 9:e93801. https://doi.org/10.1371/journal.pone.0093801 
22. Jiang D, Ge X, Zhang Q, et al (2017) Comparison of sodium hydroxide and calcium hydroxide pretreatments of giant reed for enhanced enzymatic digestibility and methane production. Bioresource Technology 244:1150-1157. https://doi.org/10.1016/j.biortech.2017.08.067

23. Fernandes TV, Klaasse Bos GJ, Zeeman G, et al (2009) Effects of thermo-chemical pre-treatment on anaerobic biodegradability and hydrolysis of lignocellulosic biomass. Bioresource Technology 100:2575-2579. https://doi.org/10.1016/j.biortech.2008.12.012

24. Yang F, Bai L, Li P, et al (2019) Improved methane production and sulfate removal by anaerobic codigestion corn stalk and levulinic acid wastewater pretreated by calcium hydroxide. Science of The Total Environment 691:499-505. https://doi.org/10.1016/j.scitotenv.2019.07.172

25. Xie S, Frost JP, Lawlor PG, et al (2011) Effects of thermo-chemical pre-treatment of grass silage on methane production by anaerobic digestion. Bioresource Technology 102:8748-8755. https://doi.org/10.1016/j.biortech.2011.07.078

26. Monlau F, Barakat A, Steyer JP, Carrere H (2012) Comparison of seven types of thermo-chemical pretreatments on the structural features and anaerobic digestion of sunflower stalks. Bioresource Technology 120:241-247. https://doi.org/10.1016/j.biortech.2012.06.040

27. Wei Y, Li X, Yu L, et al (2015) Mesophilic anaerobic co-digestion of cattle manure and corn stover with biological and chemical pretreatment. Bioresource Technology 198:431-436. https://doi.org/10.1016/j.biortech.2015.09.035

28. Venturin B, Frumi Camargo A, Scapini T, et al (2018) Effect of pretreatments on corn stalk chemical properties for biogas production purposes. Bioresource Technology 266:116-124. https://doi.org/10.1016/j.biortech.2018.06.069

29. Dahunsi SO, Osueke CO, Olayanju TMA, Lawal Al (2019) Co-digestion of Theobroma cacao (Cocoa) pod husk and poultry manure for energy generation: Effects of pretreatment methods. Bioresource Technology 283:229-241. https://doi.org/10.1016/j.biortech.2019.03.093

30. Pang YZ, Liu YP, Li XJ, et al (2008) Improving Biodegradability and Biogas Production of Corn Stover through Sodium Hydroxide Solid State Pretreatment. Energy Fuels 22:2761-2766. https://doi.org/10.1021/ef800001n

31. Sun C, Liu R, Cao W, et al (2019) Optimization of Sodium Hydroxide Pretreatment Conditions to Improve Biogas Production from Asparagus Stover. Waste Biomass Valor 10:121-129. https://doi.org/10.1007/s12649-017-0020-0

32. Song Z, Yag G, Feng Y, et al (2013) Pretreatment of Rice Straw by Hydrogen Peroxide for Enhanced Methane Yield. Journal of Integrative Agriculture 12:1258-1266. https://doi.org/10.1016/S20953119(13)60355-X

33. Shen J, Zheng Q, Zhang R, et al (2019) Co-pretreatment of wheat straw by potassium hydroxide and calcium hydroxide: Methane production, economics, and energy potential analysis. Journal of Environmental Management 236:720-726. https://doi.org/10.1016/j.jenvman.2019.01.046

34. Zhang H, Ning Z, Khalid H, et al (2018) Enhancement of methane production from Cotton Stalk using different pretreatment techniques. Sci Rep 8:3463. https://doi.org/10.1038/s41598-018-21413-x 
35. Song Z, Zhang C (2015) Anaerobic codigestion of pretreated wheat straw with cattle manure and analysis of the microbial community. Bioresource Technology 186:128-135. https://doi.org/10.1016/j.biortech.2015.03.028

36. Isci A, Demirer GN (2007) Biogas production potential from cotton wastes. Renewable Energy 32:750-757. https://doi.org/10.1016/j.renene.2006.03.018

37. Dale BE, Ong RG (2012) Energy, wealth, and human development: Why and how biomass pretreatment research must improve. Biotechnol Progress 28:893-898. https://doi.org/10.1002/btpr.1575

38. Venkateshkumar R, Shanmugam S, Veerappan AR (2021) Experimental investigation on the effect of anaerobic co-digestion of cotton seed hull with cow dung. Biomass Conv Bioref 11:1255-1262. https://doi.org/10.1007/s13399-019-00523-0

39. Venkateshkumar R, Shanmugam S, Veerappan $\operatorname{Ar}(2020)$ Anaerobic co-digestion of cow dung and cotton seed hull with different blend ratio: experimental and kinetic study. Biomass Conv Bioref. https://doi.org/10.1007/s13399-020-01006-3

40. Paritosh K, Mathur S, Pareek N, Vivekanand V (2018) Feasibility study of waste (d) potential: codigestion of organic wastes, synergistic effect and kinetics of biogas production. Int J Environ Sci Technol 15:1009-1018. https://doi.org/10.1007/s13762-017-1453-5

41. APHA (1995) Standard methods for the examination of water and waste water.American Public Health Association, Washington DC

42. Jash T, Ghosh DN (1996) Studies on the solubilization kinetics of solid organic residues during anaerobic biomethanation. Energy 21:725-730. https://doi.org/10.1016/0360-5442(95)00123-9

43. De Rossi E, Lindino CA, Cremonez PA, et al (2017) Biogas production with co-digestion of sugarcane straw. MEQ 28:94-106. https://doi.org/10.1108/MEQ-07-2015-0142

44. Şenol H (2020) Anaerobic digestion of hazelnut (Corylus colurna) husks after alkaline pretreatment and determination of new important points in Logistic model curves. Bioresource Technology 300:122660. https://doi.org/10.1016/j.biortech.2019.122660

45. Jaffar M, Pang Y, Yuan $\mathrm{H}$, et al (2016) Wheat straw pretreatment with $\mathrm{KOH}$ for enhancing biomethane production and fertilizer value in anaerobic digestion. Chinese Journal of Chemical Engineering 24:404-409. https://doi.org/10.1016/j.cjche.2015.11.005

46. Weiland $P$ (2010) Biogas production: current state and perspectives. Appl Microbiol Biotechnol 85:849-860. https://doi.org/10.1007/s00253-009-2246-7

47. You Z, Zhang S, Kim H, et al (2018) Effects of Corn Stover Pretreated with $\mathrm{NaOH}$ and $\mathrm{CaO}$ on Anaerobic Co-Digestion of Swine Manure and Corn Stover. Applied Sciences 9:123. https://doi.org/10.3390/app9010123

48. Komilis DP, Ham RK (2003) The effect of lignin and sugars to the aerobic decomposition of solid wastes. Waste Management 23:419-423. https://doi.org/10.1016/S0956-053X(03)00062-X

49. Xiao B, Sun XF, Sun R (2001) Chemical, structural, and thermal characterizations of alkali-soluble lignins and hemicelluloses, and cellulose from maize stems, rye straw, and rice straw. Polymer 
Degradation and Stability 74:307-319. https://doi.org/10.1016/S0141-3910(01)00163-X

50. Zhou S, Zhang Y, Dong Y (2012) Pretreatment for biogas production by anaerobic fermentation of mixed corn stover and cow dung. Energy 46:644-648. https://doi.org/10.1016/j.energy.2012.07.017

51. Nizami A-S, Korres NE, Murphy JD (2009) Review of the Integrated Process for the Production of Grass Biomethane. Environ Sci Technol 43:8496-8508. https://doi.org/10.1021/es901533j

52. Yu Q, Liu R, Li K, Ma R (2019) A review of crop straw pretreatment methods for biogas production by anaerobic digestion in China. Renewable and Sustainable Energy Reviews 107:51-58. https://doi.org/10.1016/j.rser.2019.02.020

53. Dai B, Guo X, Yuan D, Xu J (2018) Comparison of Different Pretreatments of Rice Straw Substrate to Improve Biogas Production. Waste Biomass Valor 9:1503-1512. https://doi.org/10.1007/s12649017-9950-9

54. Liew LN, Shi J, Li Y (2011) Enhancing the solid-state anaerobic digestion of fallen leaves through simultaneous alkaline treatment. Bioresource Technology 102:8828-8834. https://doi.org/10.1016/j.biortech.2011.07.005

55. Reilly M, Dinsdale R, Guwy A (2015) Enhanced biomethane potential from wheat straw by low temperature alkaline calcium hydroxide pre-treatment. Bioresource Technology 189:258-265. https://doi.org/10.1016/j.biortech.2015.03.150

\section{Figures}




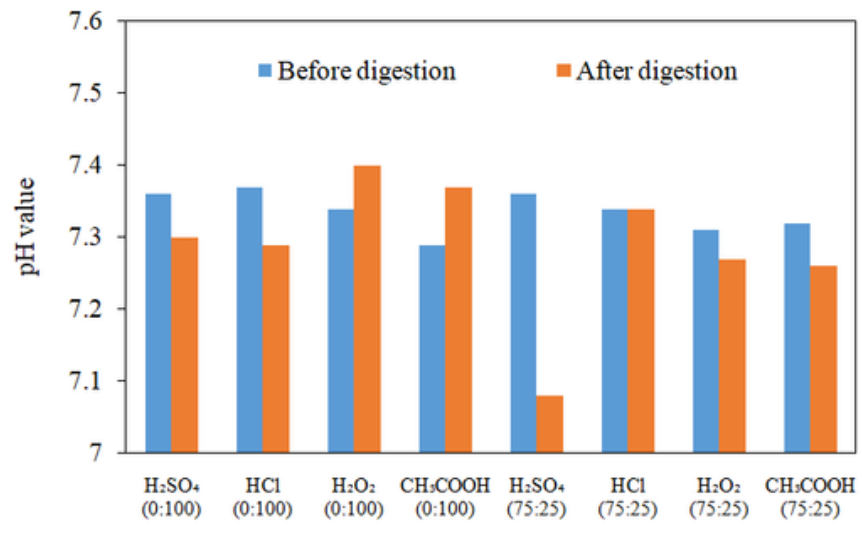

(a) $1 \%$ concentration

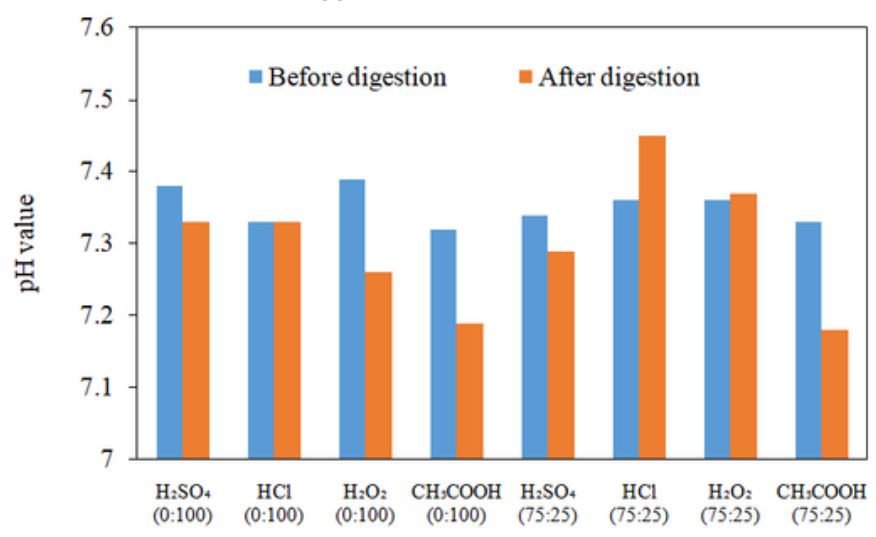

(b) $2 \%$ concentration

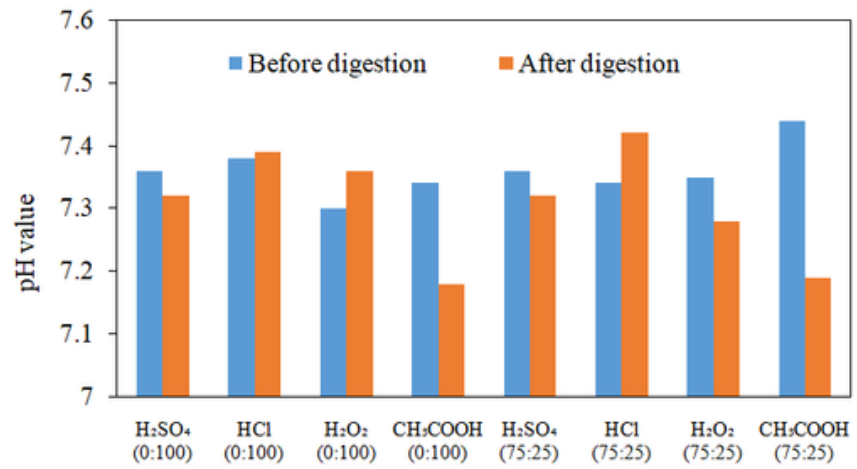

(c) $3 \%$ concentration

\section{Figure 1}

$\mathrm{pH}$ values of acid treated reactors 


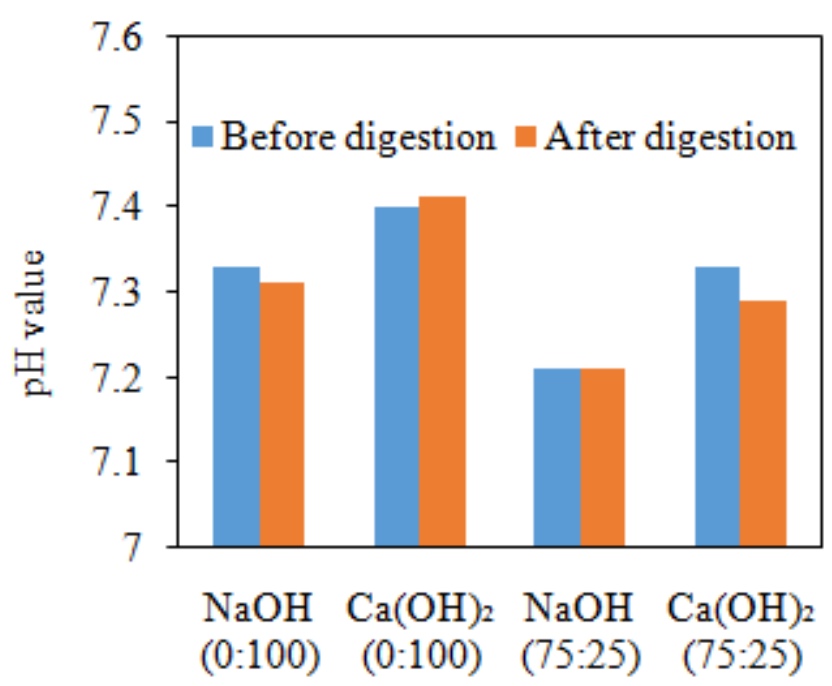

(a) $4 \%$ concentration

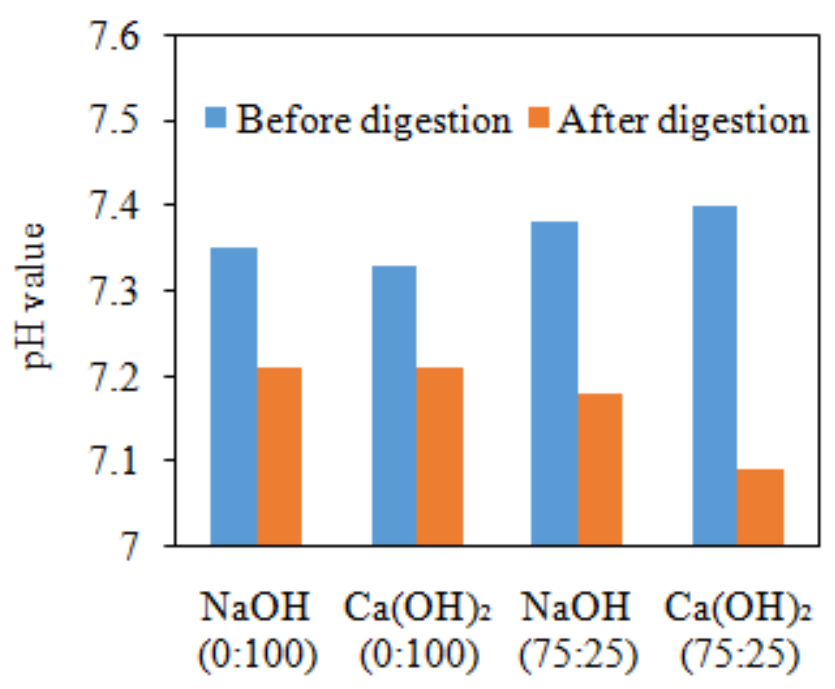

(b) $6 \%$ concentration

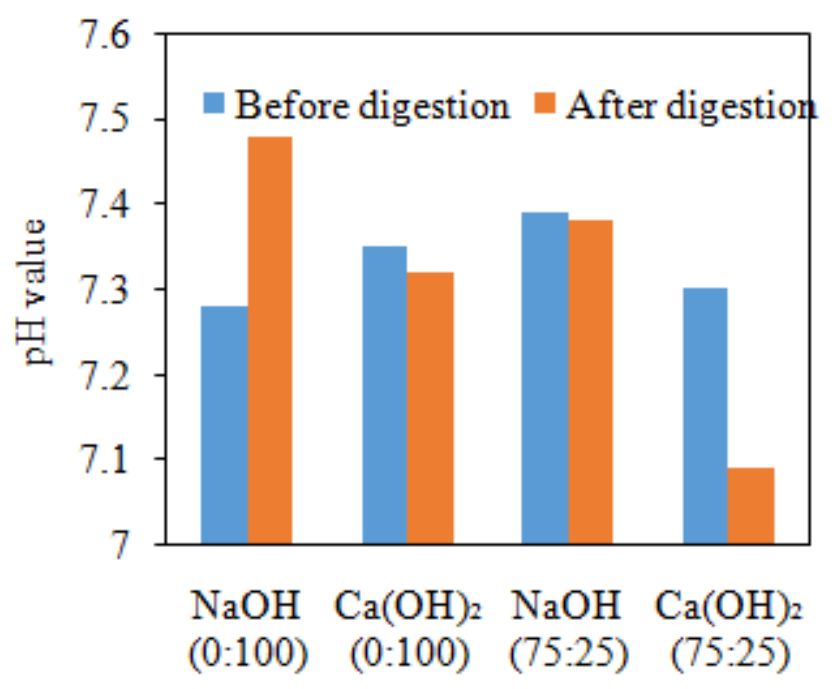

(c) $8 \%$ concentration

\section{Figure 2}

$\mathrm{pH}$ values of alkaline treated reactors 


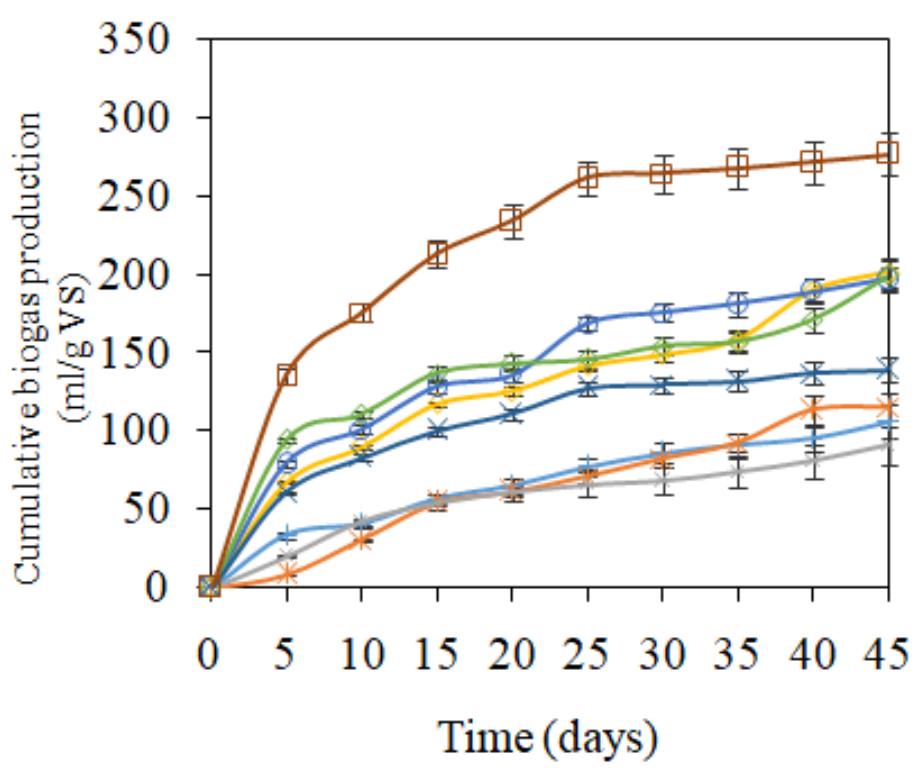

(a) $1 \%$ concentration

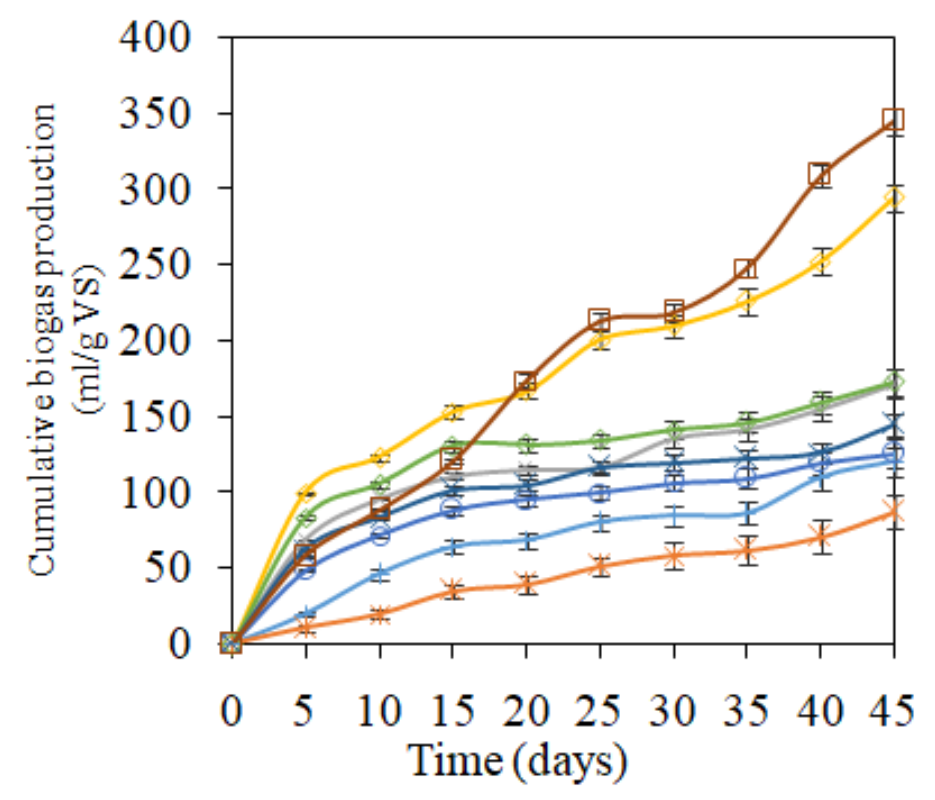

(c) $3 \%$ concentration

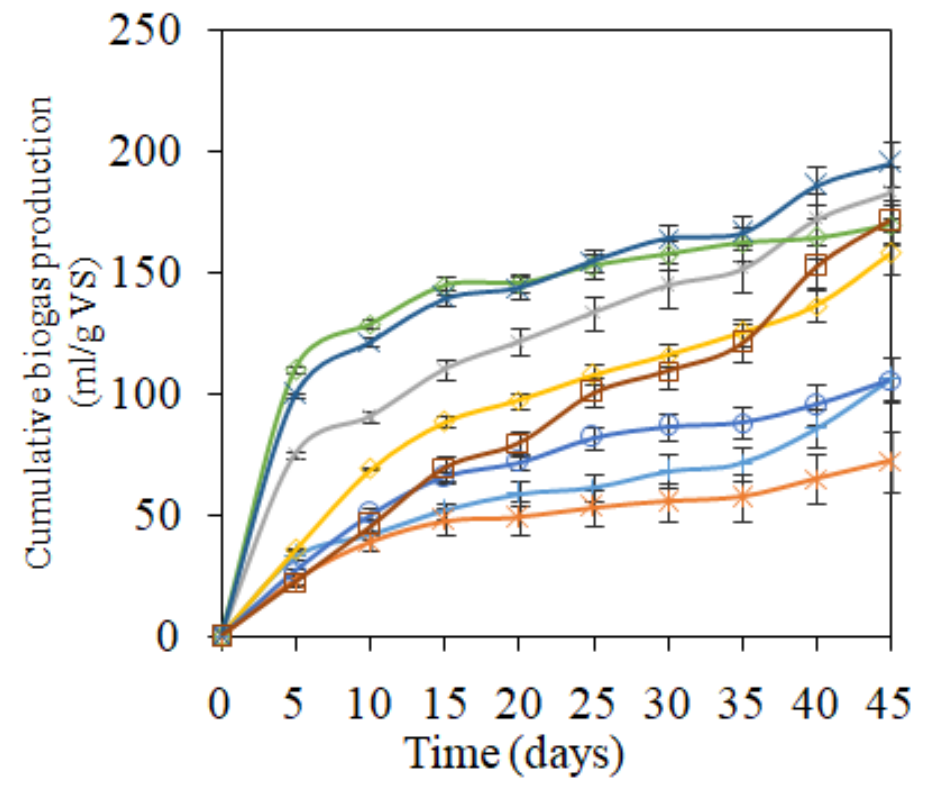

(b) $2 \%$ concentration

Figure 3

Biogas production from acid treated reactors 


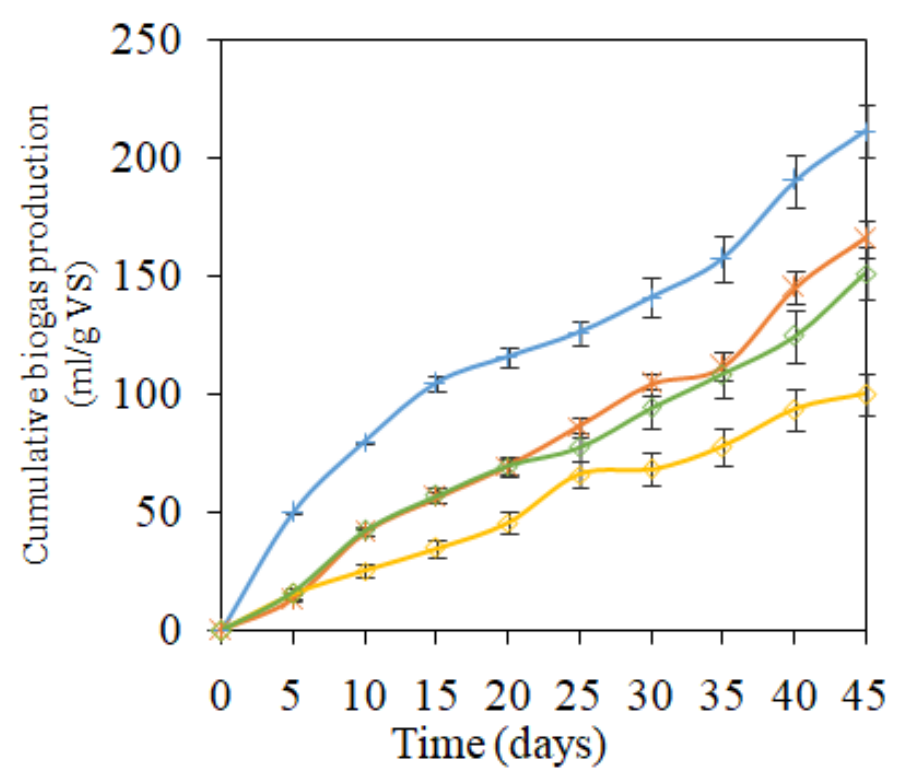

(a) $4 \%$ concentration

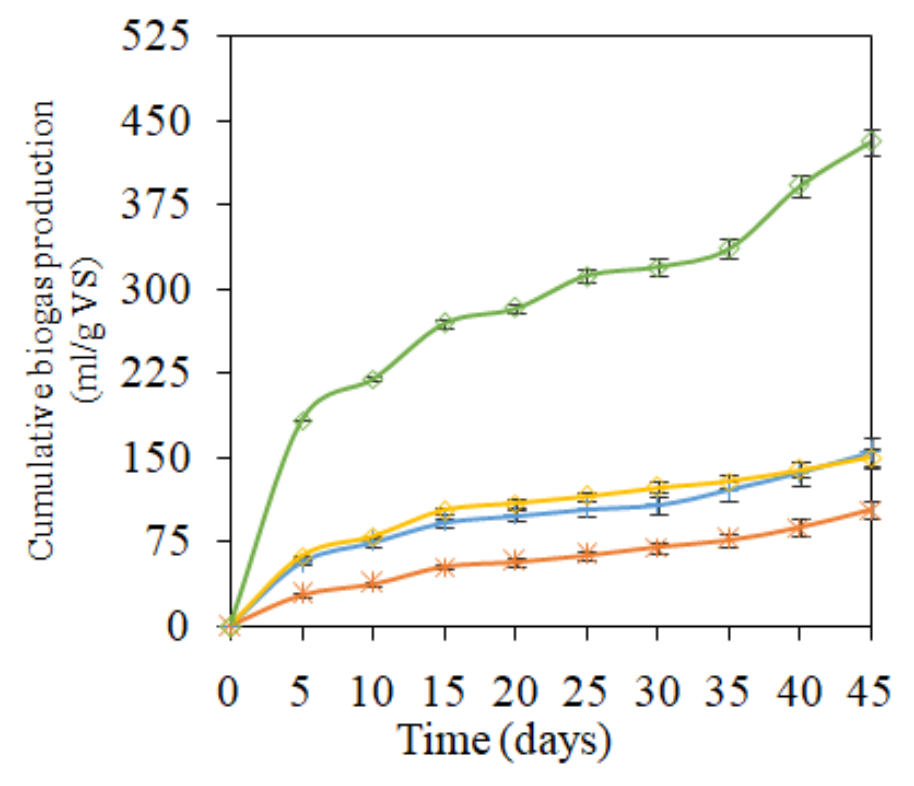

(c) $8 \%$ concentration

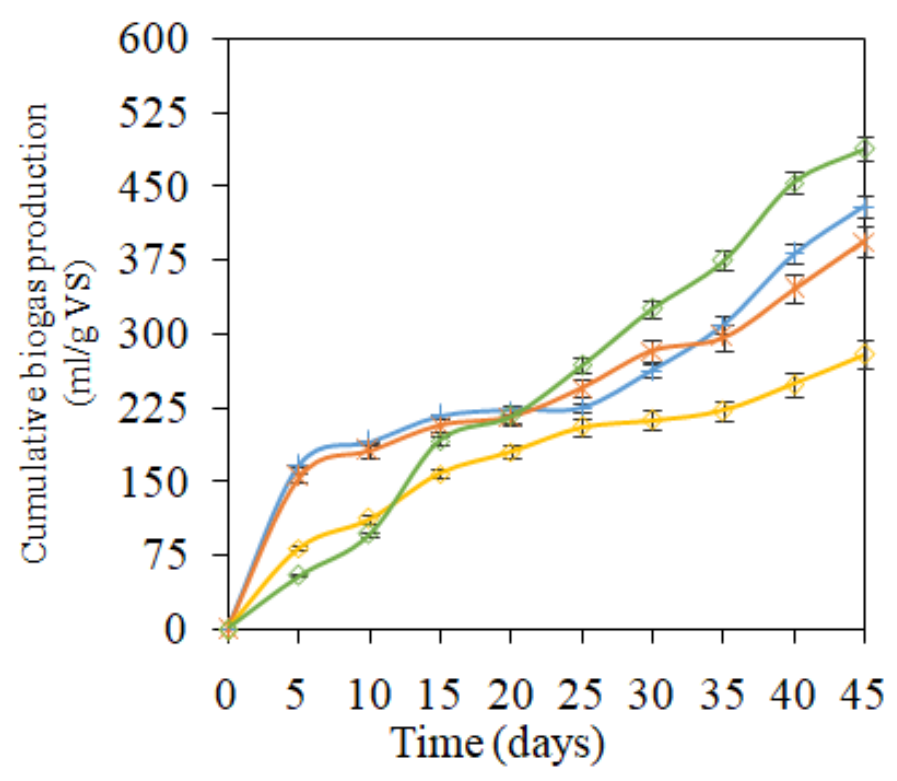

(b) $6 \%$ concentration

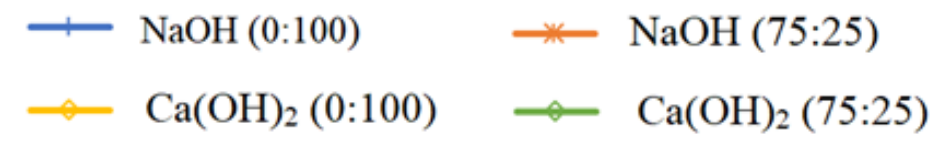

\section{Figure 4}

Biogas production from alkaline treated reactors

\section{Supplementary Files}

This is a list of supplementary files associated with this preprint. Click to download.

- GraphicalAbstract.docx 